\title{
Preliminary Comments on Dog Interments from Archeological Sites in Northeast Texas: Folklore and Archeology
}

Jesse Todd

Unknown

Follow this and additional works at: https://scholarworks.sfasu.edu/ita

Part of the American Material Culture Commons, Archaeological Anthropology Commons, Environmental Studies Commons, Other American Studies Commons, Other Arts and Humanities Commons, Other History of Art, Architecture, and Archaeology Commons, and the United States History Commons

Tell us how this article helped you.

This Article is brought to you for free and open access by the Center for Regional Heritage Research at SFA ScholarWorks. It has been accepted for inclusion in Index of Texas Archaeology: Open Access Gray Literature from the Lone Star State by an authorized editor of SFA ScholarWorks. For more information, please contact cdsscholarworks@sfasu.edu. 
Preliminary Comments on Dog Interments from Archeological Sites in Northeast Texas: Folklore and Archeology

\section{Creative Commons License}

(c) (1) (8)

This work is licensed under a Creative Commons Attribution-NonCommercial 4.0 International License 


\title{
Preliminary COMmENTS ON DOG INTERMENTS FROM ArChEOlogical Sites in Northeast Texas: FOLKLORE AND ARCHEOLOGY
}

\author{
Jesse Todd
}

\section{Introduction}

Dogs have been associated with humans for thousands of years, and dog interments-either associated with human interments or as separate interments-also have an antiquity of thousands of years. This brief paper will summarize dog burials in a worldwide context, and then focus on the folklore, ethnology, and archeology of dogs among the Caddo. The information for the dog in Caddo culture will be summarized from George A. Dorsey's (1905) Traditions of the Caddo and John R. Swanton's (1942) Source Material on the History and Ethnology of the Caddo Indians. Then, dog interments from northeast Texas will be listed and discussed. By examining the folklore, ethnology, and archeology of the dog in Caddo contexts, it is hoped that a greater understanding of the role of dogs in prehistoric Caddo culture might be attained.

\section{Dog Burials and Ethnology outside the Caddo Area}

Dogs are thought to have first evolved from wolves roughly 16,000 years ago in China, but recent research based on DNA has suggested that dogs may have evolved from wolves in different places at different times. It is suggested that dogs also evolved from wolves in North America, but later than in China. The oldest recorded dog burial is located in Germany and dates to approximately 14,000 years ago. A dog was buried with two humans (Lobell and Powell 2010).

The domestication of dogs may be related to their hunting/herding capabilities, their companionship, vigilance and/or perhaps for their utility as a food resource. The earliest recorded genetically identified dog (ca. $9260 \pm 170$ B.P.) in Texas was used as food by Paleoindian inhabitants of the Hinds Cave site (41VV456) in Val Verde County which is located in southwestern Texas (Tito et al. 2011). Dogs have been sacrificed in ancient Greece and used as offerings in ancient Egypt. They have been used as "war dogs" by the $16^{\text {th }}$ century Spanish in the Americas, and the ancient Greeks and Romans believed that the entrance to Hades was guarded by a three-headed dog. The Aztecs believed that one could enter the afterlife by hanging on the tail of a dog. In the prehistoric American southwest, dogs were perceived as guides to the spirit world. Rock art in Utah dating before A.D. 1300 suggests an association of the dog with shamans. Prior to A.D. 1300, dog burials in the southwest are prevalent, but not so much later in time. It is suggested that there was a change in the belief system circa A.D. 1300, from shamanistic beliefs to the kachina cult. With this change, dogs were no longer perceived as spiritual escorts and, therefore, were not as commonly interred with humans (Lobel and Powell 2010) 


\title{
Folklore and Ethnology
}

According to George A. Dorsey (1905) in his study of Caddo folklore, dogs were familiar to and trusted by all of the first inhabitants of the Earth. The dogs guarded the house, were truth-tellers and were even a little bit of a gossip. They appear to be associated with men and hunting. A special relationship existed between one man and his dog because they both turned themselves into stars to escape this dangerous world Dorsey (1905:25).

Dorsey [cited in Swanton (1942:307-308)] learned the following from the Caddo informant, WhiteBread:

\begin{abstract}
"There are six bad places on the way to the spirit-land. The first place is where the dogs stay. If you whip or mistreat or kill a dog, the dog, when it dies, goes to its people and tells what you have done. When you die, you have to pass the place of the dogs, and the chief of the dogs goes and sits by the road and waits for you. When you come he tells you to look for fleas on his head, and when you find one he tells you to bite it. When you bite it, you become a dog. Then he takes you to where the dogs stay, and there they mistreat you as you mistreated them on earth. They keep you there and never let you get away, so that you can not continue your journey. For this reason, we place a bead on the little finger of a dead person, so that he may bite it instead of the flea, and so fool the dog and escape him."
\end{abstract}

Swanton relates that dogs were the only domesticated animal which the Caddo possessed at the time of European contact, and that dogs were eaten in times of famine, or as part of ceremonial occasions. Father Solís [cited in Swanton (1942:123)] notes that the dogs of the Caddo were called "jubines." These dogs had long, pointed snouts, and are described as being “... very intelligent and cunning as well as great thieves" (Swanton 1942:134).

\section{Archeology}

Burial information for deliberate dog (Canis familiarius) interments recovered from ten Caddo archeological sites in northeast Texas is provided in Table 1. Counties where the interments were discovered are presented in Figure 1.

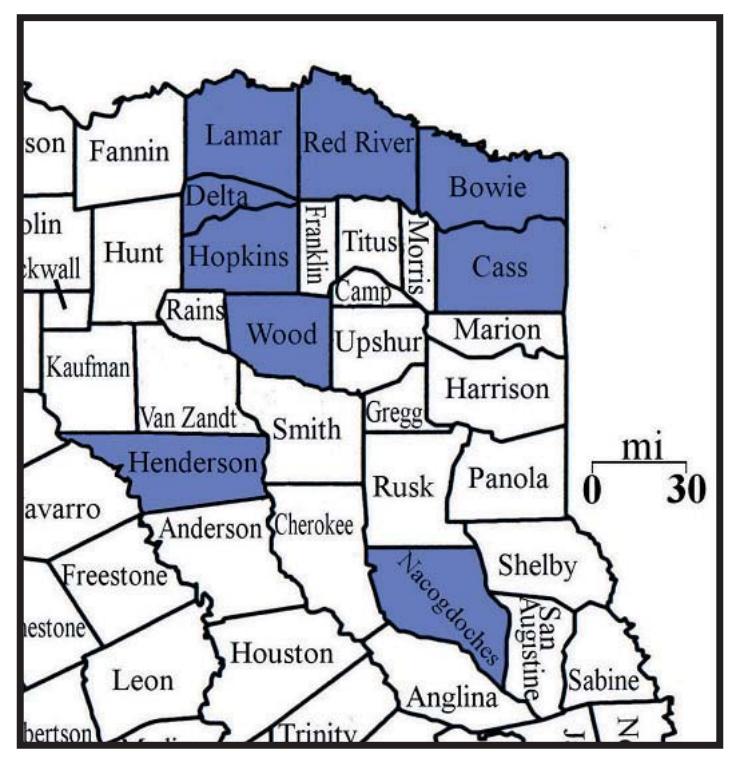

Figure 1. Counties in northeast Texas where dog interments have been discovered. 


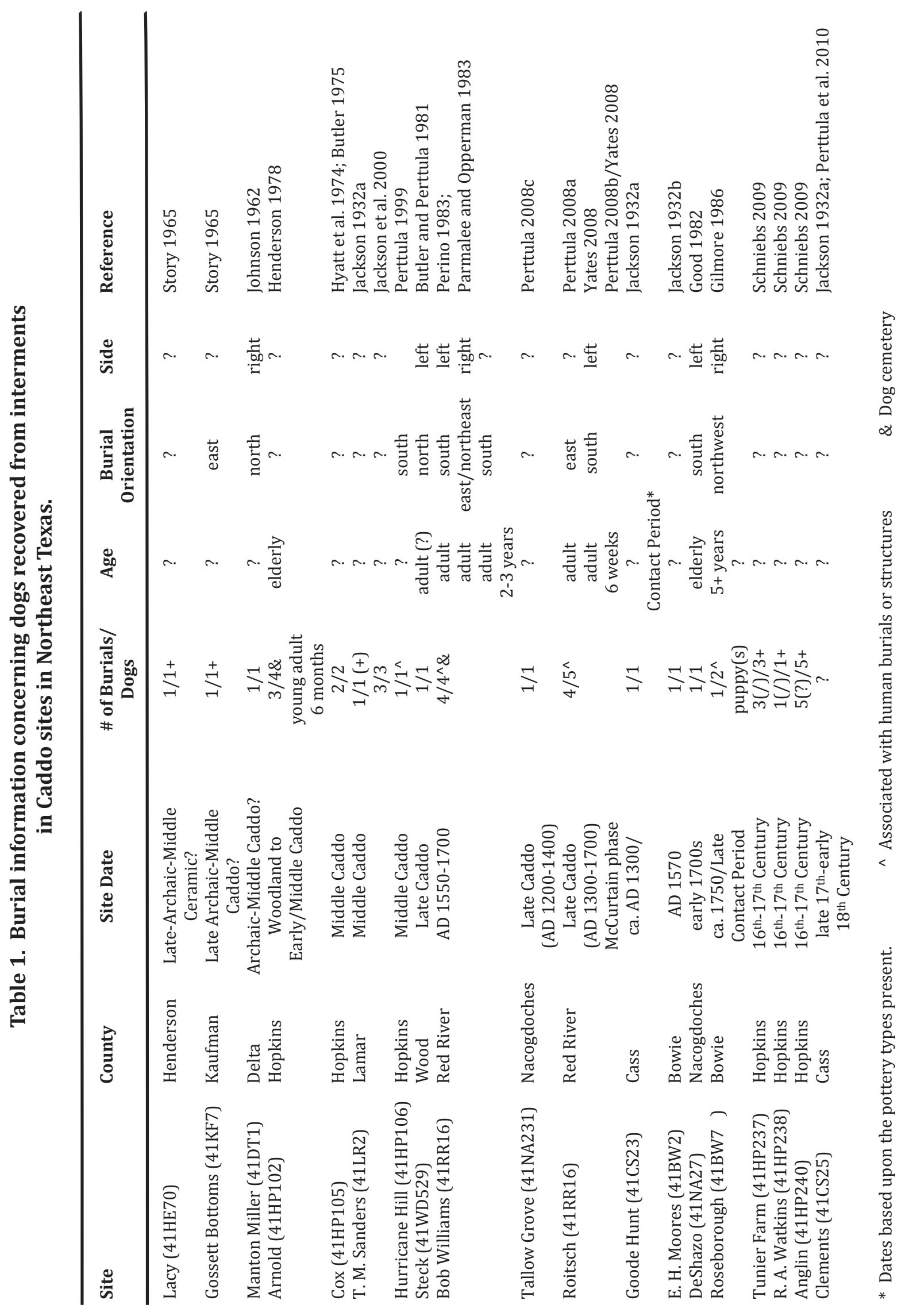


Dog interments sometime occur in groups. For example, four dogs were uncovered at the Bob Williams site (41RR16) in a special cemetery between House patterns 2 and 4 (Perino 1983:47). Burial 3 was about 30 centimeters from a human child in or near House 4. Dog interments 1, 2 and 3 were close together north the human burial Number 36 in House complex 2 (Perino 1983:47).

Esteem for dogs is indicated by the presence of burial furniture or special treatment. The puppy in Burial 3 at the Bob Williams site was buried with a small, shallow bowl that may have contained food (Parmalee and Opperman 1983:79, 81). Parmalee and Opperman (1983:81) mention that the burial of the puppy was unusual if not unique and the puppy may have been the pet of a child. A dog interment from the Goode Hunt Farm site (41CS23) in Cass County contained a small jar (Jackson 1932a:15). Jackson and others state that the jar probably was a mark of esteem from the dog's owner. In a Late Caddo burial at the Roitsch site, a small ceramic sherd was found near its eye which might be a form of burial furniture (Figure 2) (Yates 2008:474). Perttula (2008b:372-373) writes that the burial of a puppy adjacent to a Late McCurtain phase human cemetery was special. The burial was overlaid by a clay cap that may have been a result of a house floor, but may have been a deliberate capping as a special treatment. The puppy would have been approximately 6 weeks old at death (Yates 2008:474). Possibly more than one puppy was in the grave.

Other dog interments have been discovered near residences and human cemeteries. During the excavation of the Middle Caddo component of the Hurricane Hill site (41HP106), a dog interment was discovered outside of and near the southeast corners of two houses (Perttula 1999:101). Also within the Late McCurtain portion of the Roitsch site, two dogs were super-imposed in a double burial. The later interment had an outstretched leg which may indicate a difference in the disposal ritual due to either temporal or ritualistic changes. The dog interments were located west of and adjacent to the human cemetery.

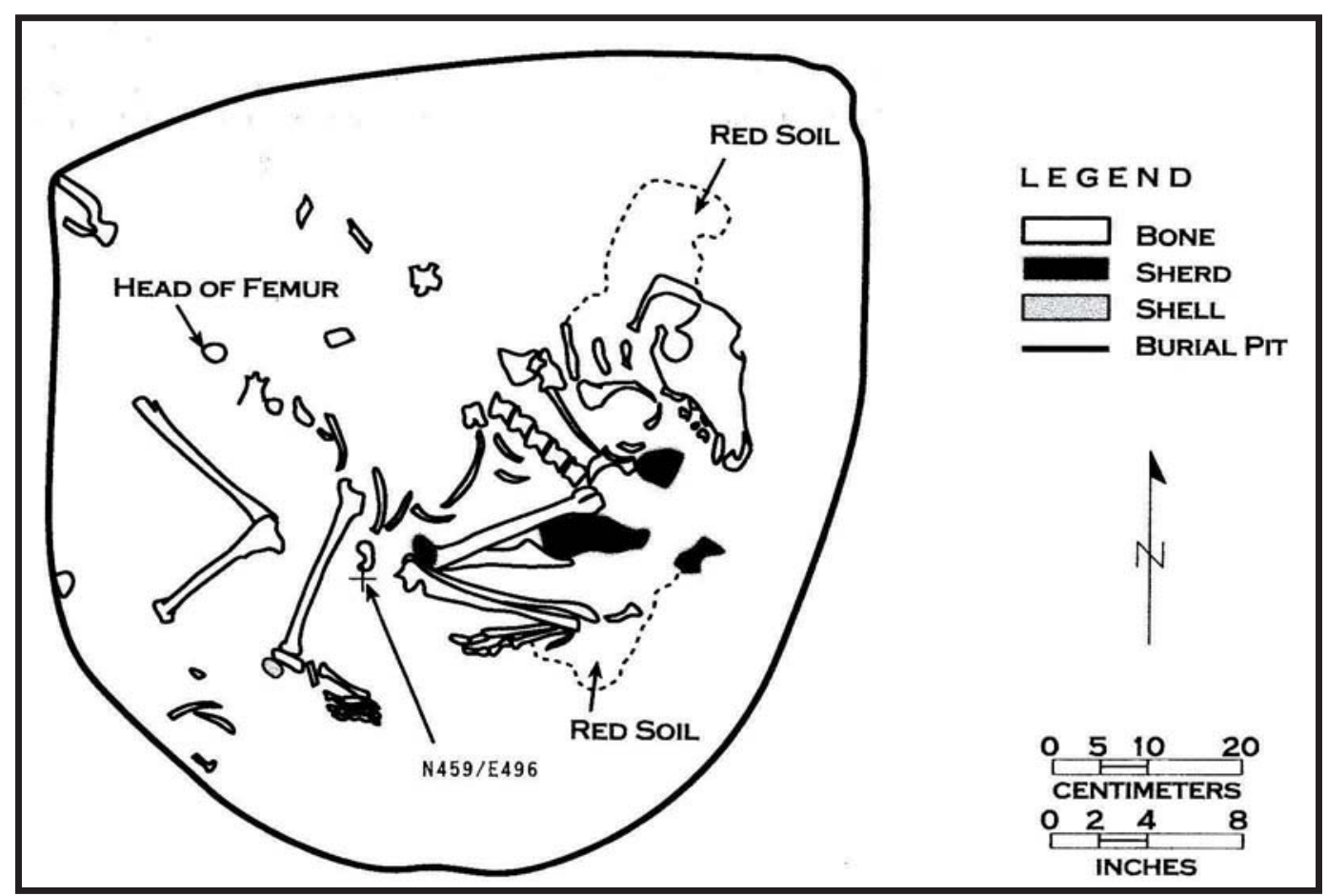

Figure 2. Dog interment from Feature 346 of the Roitsch Site (41RR16) (Perttula 2008a:347). Reproduced with the permission of the Texas Archeological Society. 
Jackson (1932b:7) describes the dog burial at the E. H. Moores Plantation site (41BW2) as if it was hurried. The dog was crumpled as if the dog was forced into a small hole. At the Roseborough Lake site (41BW7) in Bowie County a female dog apparently died during the whelping process because at least one puppy's skeletal remains were found in the burial (Gilmore 1986:118-120). Interestingly, the dog was buried near a smudge pit which is considered a female activity area. Gilmore states that the dog may have been a favorite pet of a Native American woman and the woman buried the dog near her working area, or possibly, in addition, her house.

\section{Discussion}

In Caddo folklore, the dog has "supernatural" powers. It has the ability to become a star and lives in a village similar to the Caddo. The Chief-of-the-Dogs also can transform a human into a dog. Interestingly, in the tale, there is a moral lesson on how to treat dogs on Earth, further indicating that they are regarded as special. The dogs have the potential for "payback" which is a human emotion.

Based upon the excavations of the Bob Williams site (41RR16), Perino (1983:49) writes that there must have been a special relationship between the Caddo and their dogs or they would not have buried them in specially prepared graves and, especially, next to children. He further lists the importance of dogs to the Caddo for hunting, acting as sentinels, as pack animals and as food during famine. Henderson (1978:105) states that the dogs discovered during the excavations at the Arnold site probably were pets and were not used for food. Hill (2000:387) states that burials of dogs in cemeteries may reflect their social behavior in life-their closeness to each other as well as humans formed the basis for their interments in groups.

It appears that dog interments have been found from archeological sites that possibly range from Early Caddo to post-European contact times in northeast Texas. Most of the interments, however, appear to be from Middle Caddo to post-contact sites. This may be due to a preference for excavating sites from this time period; however, no dog interments were reported from the George C. Davis site (Newell and Krieger 1949; Story 1981) which generally dates from circa A.D. 700 to 1300. Interestingly, separate dog interments have been found from the Middle Caddo and possible Late Caddo times. It also appears that dogs are associated with human burials and structures during Middle Caddo to later times.

Butler and Perttula (1981:123) state that according to Jackson, dog burials are common in the Lake Fork area during Late Caddo times. The dogs range in age from puppies to elderly adults. The preferential burial direction appears to be south, but which side the dog was laid on appears not to be important. Dog interments are not plentiful when compared to the total number of archeological sites excavated in Northeast Texas. Twothirds of the interred dogs in this study come from two counties, Red River and Hopkins. Two sites in Red River County, the Roitsh and Bob Williams sites - which are adjacent to each other-total nine burials. Five burials are from Hopkins County, four burials from the Arnold site and one from the Hurricane Hill site. The rest of the counties only have one or two recorded burials. According to Figure 1, most of the interments were found in northern northeast Texas, the exception being the Deshazo site in Nacogdoches County and the Lacy site in Henderson County.

\section{Conclusions}

The archeological evidence does support the importance of the dog to the Caddo. Although the archeological evidence is scanty, puppies may have been revered more than adult dogs since one puppy was buried possibly with food and one may have had a clay cap over the interment. There may have been a change in the burial practices for the dog over time, but further information is needed to support this. Unfortunately, at this stage, no relation between the archeological information and the folklore can be presented, except, as previously mentioned, the importance of the dog to the Caddo. 


\section{References Cited}

Butler, Barbara H.

1975 Faunal Remains. In Archeological Research at the Copper Lake, Northeast Texas, 1973, by R. Hyatt and K. Doehner, pp. 61-66, Contributions in Anthropology 15, Department of Anthropology, Southern Methodist University, Dallas, Texas.

Butler, Barbara H. and Timothy K. Perttula

1981 Subsistence Analysis. In Prehistoric Settlement Patterns at Lake Fork Reservoir, by J. E. Bruseth and T. K. Perttula, pp. 117-125, Texas Antiquities Permit Series No. 2., Archaeology Research Program, Southern Methodist University, Dallas, Texas and Texas Antiquities Committee, Austin.

Dorsey, George A.

1905 Caddo Customs of Childhood. Journal of American Folk-Lore 8:226-228.

1997 Traditions of the Caddo. Introduction by Wallace L. Chafe. University of Nebraska Press, Lincoln.

Gilmore, Kathleen

1986 French-Indian Interaction at an $18^{\text {th }}$ Century Frontier Post: The Roseborough Lake Site, Bowie County, Texas. Contributions in Archeology No. 3, Institute of Applied Sciences, University of North Texas, Denton.

Good, Carolyn E.

1982 Analysis of Structures, Burials, and Other Cultural Features, In The Deshazo Site Nacogdoches County, Texas, Volume I: The Site, Its Setting, Investigation, Cultural Features, Artifacts of Non-Native Manufacture, and Subsistence Remains, edited by Dee Ann Story, pp. 51-112, Texas Antiquities Permit Series, No. 7, Texas Antiquities Committee, Austin.

Henderson, Jerry

1978 The Vertebrate Fauna. In Archaeological Research at the Proposed Cooper Lake, Northeast Texas, 1974-1975, by K. Doehner and R. E. Larson, pp. 99-114, Research Report No. 108, Archaeology Research Program, Southern Methodist University, Dallas, Texas.

Hill, Erica

2000 The Contextual Analysis of Animal Interments and Ritual Practices in Southwest North America. Kiva 65(4):361-398.

Hyatt, R. D., B. H. Butler and H. P. Mosca

1974 Archaeological Research at Cooper Lake, 1970-1972. Contributions in Anthropology 12, Department of Anthropology, Southern Methodist University, Dallas, Texas.

Jackson, A. T.

1932a Exploration of a Burial Site on Goode Hunt (Negro Farm) in Cass County, Texas. Notes on file at the Texas Archeological Research Laboratory, The University of Texas at Austin.

1932b Exploration of a Burial Site on E. H. Moore's Plantation in Bowie County, Texas. Notes on file at the Texas Archeological Research Laboratory, The University of Texas at Austin. 


\section{References Cited (cont.)}

Jackson, A. T., Marcus S. Goldstein and Alex D. Krieger

2000 The 1931 Excavations at the Sanders Site Lamar County, Texas. Notes on the Fieldwork, Human Osteology, and Ceramics. Forward by Frank Schambach. Archival Series 2, Texas Archeological Research Laboratory, The University of Texas at Austin.

Johnson, LeRoy, Jr.

1962 The Yarborough and Miller Sites of Northeastern Texas, With a Preliminary Definition of the La Harpe Aspect. Bulletin of the Texas Archeological Society 32:141-284. The George C. Engerrand Volume.

Lobel, Jarrett A. and Eric Powell

2010 More than a Man's Best Friend. Archaeology 65(3). Electronic document. http://www.archaeology.org/1009/dogs/. (Accessed December 18, 2012.)

Newell, H. Perry and Alex D. Krieger

1949 The George C. Davis Site, Cherokee County, Texas. Memoirs of the Society for American Archaeology (American Antiquity XIV(4), Part 2 and the University of Texas, Austin.

Parmalee, Paul W. and Anthony F. Opperman

1983 Animal Remains from the Bob Williams Site, Red River County, Texas. In Archaeological Research at the Bob Williams Site (41RR16) Red River County, Texas. by G. Perino, pp. 79-84, Potsherd Press, Museum of the Red River, Idabel, Oklahoma.

Perino, Gregory

1983 Archaeological Research at the Bob Williams Site (41RR16) Red River County, Texas. Potsherd Press, Museum of the Red River, Idabel, Oklahoma.

Perttula, Timothy K.

1999 Cultural Features. In The Hurricane Hill Site (41HP106): The Archeology of a Late Archaic/Early Ceramic and Early-Middle Caddoan Settlement in Northeast Texas, Vol. 1, edited by T. K. Perttula, pp. 81-120, Special Publication No. 4, Friends of Northeast Texas Archaeology.

2008a Archeological Investigations in the Late Caddo Village Area of the Roitsch Site. In The Archeology of the Roitsch Site (41RR16), an Early to Historic Caddo Period Village on the Red River in Northeast Texas, edited by T.K. Perttula, pp. 342-362, In Texas Archeological Society Special Publication No. 5, edited by T. K. Perttula, pp. 313-628, Austin, Texas.

2008b Excavations in a Late McCurtain Phase Cemetery: Terrace Area (Block VII). In The Archeology of the Roitsch Site (41RR16), an Early to Historic Caddo Period Village on the Red River in Northeast Texas, edited by T.K. Perttula, pp. 362-380, In Texas Archeological Society Special Publication No. 5, edited by T. K. Perttula, pp. 313-628, Austin, Texas.

2008c Lake Naconiche Archeology, Nacogdoches County: Results of the Data Recovery Excavations at Five Prehistoric Archeological Sites, Volumes I and II, Nacogdoches County, Texas. Report of Investigations No. 60, Archeological and Environmental Consultants, LLC, Austin, Texas.

2010 Email to the author on Caddo ritual animal burials. June 23, 2010.

2012 Email to the author on age of E. H. Moores Plantation site. December 22, 2012. 


\section{References Cited (cont.)}

Perttula, T. K., B. Nelson, R. L Cast and B. Gonzalez

2010 The Clements Site (41CS25): A Late 17 th- to Early $18^{\text {th }}$-Century Nasoni Caddo Settlement and Cemetery. Anthropological Papers of the American Museum of Natural History, Number 92, American Museum of Natural History, New York, New York.

Schniebs, LeeAnna

2009 Faunal Analysis of Three Late Caddo Sites in Hopkins County, Texas: Tuinier Farm, Anglin Midden, and the R. A. Watkins Site. In The Archaeology of the $16^{\text {th }}$ and $17^{\text {th }}$ Century Caddo in the Post Oak Savannah of Northeast Texas: The Tuinier Farm (41HP237), R. A. Watkins (41HP238), and Anglin (41HP240) Sites in the Stouts Creek Basin, Hopkins County, Texas, edited by T. K. Perttula, pp. 6679, Journal of Northeast Texas Archaeology 30:1-132.

Story, Dee Ann

1965 The Archeology of Cedar Creek Reservoir, Henderson and Kaufman Counties, Texas. Bulletin of the Texas Archeological Society 36:163-157.

Story, Dee Ann, Editor

1981 Archeological Investigations at the George C. Davis Site, Cherokee County, Texas: Summers of 1979 and 1980. Occasional Papers, No. 1, Texas Archeological Research Laboratory, The University of Texas at Austin.

Swanton

1942 Source Material on the History and Ethnology of the Caddo Indians. Foreward by Helen Hornbeck Turner. University of Oklahoma Press, Norman.

Tito, R. Y., S. L. Belknap III, K. D. Sobolik, R. C. Ingraham, L. M. Cleeland and C. M. Lewis, Jr.

2011 Brief Communication: DNA from Early Holocene American Dog. American Journal of Physical Anthropology 145:653-657.

Yates, Bonnie C.

2008 Observations on the Faunal Remains from the 1991 Field School on the Red River in Red River County, Texas. In The Archeology of the Roitsch Site (41RR16), an Early to Historic Caddo Period Village on the Red River in Northeast Texas, edited by T.K. Perttula, pp. 458-478, In Texas Archeological Society Special Publication No. 5, edited by T. K. Perttula, pp. 313-628, Austin, Texas. 